\title{
Proteome and fermentative parameters of Saccharomyces cerevisiae CAT-1 under Very High Gravity Fermentation (VHGF) using sugarcane juice
}

\author{
Gabriela de Sá Azarias ${ }^{1}$, Heloisy Suzes Barbosa ${ }^{1}$, Cynthia Barbosa Rustiguel ${ }^{2}$, José Cesar Rosa ${ }^{3}$, \\ José Roberto Ernandes ${ }^{1}$, Luis Henrique Souza Guimarães ${ }^{2 *}$ \\ ${ }^{1}$ Institute of Chemistry of Araraquara - UNESP. Rua Prof. Francisco Degni 55, 14800-900 Araraquara, São Paulo, Brazil. \\ ${ }^{2}$ Department of Biology, Faculty of Philosophy, Science and Letters of Ribeirão Preto, University of São Paulo - USP, Avenida Bandeirantes 3900, 14040- \\ 901 Ribeirão Preto, São Paulo, Brazil. ${ }^{3}$ Department of Molecular and Cell Biology and Pathogenic Bioagents, Faculty of Medicine of Ribeirão Preto, \\ University of São Paulo - USP, Avenida Bandeirantes 3900, 14040-901 Ribeirão Preto, São Paulo, Brazil.
}

\begin{tabular}{l}
\hline ARTICLE INFO \\
\hline Article history: \\
Received on: $17 / 02 / 2017$ \\
Accepted on: 07/04/2017 \\
Available online: 14/08/2017 \\
\hline Key words: \\
Alcoholic fermentation; \\
Saccharomyces cerevisiae; \\
Saccharomyces proteome; Very \\
High Gravity Fermentation.
\end{tabular}

\begin{abstract}
Alcoholic fermentation is an important process in the modern world, allowing the production of ethanol for several applications. Different Saccharomyces cerevisiae strains have been used for this purpose, such as CAT-1, a strain resistant to different stress factors. Hence, our aim was to analyze some fermentative parameters and the proteome of S. cerevisae CAT-1 under Very High Gravity Fermentation (VHGF) using sugarcane juice as fermentative medium. The yeast was cultured in the must with the sucrose concentration adjusted to $2 \%, 14 \%, 21 \%$ and $30 \%$, for $10 \mathrm{~h}$ at $30{ }^{\circ} \mathrm{C}$. The cell viability was $96-100 \%$ for all sucrose concentrations analyzed and the biomass increased for each condition as time function. The highest ethanol recovery was obtained under $30 \%$ sucrose. Considering the S. cerevisiae CAT- 1 proteome under $14 \%$ and $30 \%$ sucrose, qualitative and quantitative differences were found in the protein expression. Important enzymes for fermentation, such as enolase and one alcohol dehydrogenase isoform were more expressed at $30 \%$ sucrose than with $14 \%$ sucrose. The yeast $S$. cerevisiae CAT-1 is an interesting strain to be used for fermentation under VHGF technology using sugarcane juice, allowing high ethanol recovery with increased expression of proteins related to alcoholic fermentation and viability as well.
\end{abstract}

\section{INTRODUCTION}

Alcoholic fermentation is an important process nowadays, allowing the production of ethanol for several applications, especially as fuel. This process has been conducted using different strains of the yeast Saccharomyces cerevisiae. When a microorganism is submitted to the anaerobic condition or to the medium containing high sugar concentration, the fermentation can be conducted effectively [1]. The fermentative process used in the Brazilian industries, which uses sugar-cane juice and/or molasses as fermentative medium, is characterized by high cellular density, short period of fermentation $(6-11 \mathrm{~h})$ at $32-35^{\circ} \mathrm{C}$ and recycling of yeast cells, with recovery of $8-11 \%(\mathrm{v} / \mathrm{v})$ of

\footnotetext{
* Corresponding Author

Luis Henrique Souza Guimarães, Faculty of Philosophy, Science and Letters of Ribeirão Preto, University of São Paulo - USP, Brazil.

Email: lhguimaraes@ffclrp.usp.br
}

ethanol concentration [1]. However, an important challenge in this scenario is to increase the ethanol production in the fermentative process. Focused on this aim, different wild S. cerevisae strains, such as CAT-1 and PE-2, isolated from Brazilian distilleries as indigenous, have been used by different industries from the alcoholic sector [2]. The choice of a yeast strain for a fermentative process depends on different microbial characteristics as the velocity of transformation of the sugars into ethanol, resistance to high ethanol concentration, resistance to modifications of $\mathrm{pH}$ and temperature, genetic stability and insensitivity to antibiotics [3]. The yeast $S$. cerevisae CAT-1, isolated from a Brazilian distillery in 1998, is an important strain that can be used for alcoholic fermentation because of its resistance to different stress factors such as increased temperature and high concentration of sugars in the medium $[4,5]$. In addition, it is a flocculent microorganism with reduced production of spume during the industrial process [4]. 
The genome $(\sim 12-\mathrm{Mb})$ analysis of the CAT-1 strain indicated that this yeast is a heterozygous diploid with low occurrence of transposable elements, gene duplication and deletions as well. Some genes are involved with important ways for ethanol production [6]. Recently, a quantitative proteomic analysis for this strain was performed, showing high fermentative performance and robustness when compared to PE-2 strain. Additionally, proteins associated to trehalose synthesis and to oxidative stress were abundant under batch fermentation [2]. Considering the robustness of the CAT-1 strain, engineered $S$. cerevisiae strains able to ferment D-xylose were reported, as well as their potential for ethanol production using corncob hydrolysate [7].

According to Carvalho and Sato (2011) [8], the microbial metabolism can be dislocated to a specific metabolic way by controlling the volume of the substrate in the reactor, allowing the accumulation of the product (in this case, ethanol) and reducing the production of vinasse. However, this process uses around of $21 \%$ of dissolved solids $\left(21^{\circ}\right.$ BRIX) in the medium, what produces a wine with low ethanol concentration and high volumes of vinasse that can cause serious environmental problems [9, 10]. This technology is known as High Gravity Fermentation (HGF), recovering $10-12 \%$ ethanol at the end of the process. An interesting alternative to HGF is the Very High Gravity Fermentation (VHGF) technology, which uses a concentration of dissolved solids $\geq 27 \%$ ( $/ \mathrm{v})$, allowing the reduction of bacterial contamination, ethanol recovery of $15-18 \%$ at the end of the process, reduction in the volume of vinasse produced and water and energy economy [12]. Under this scenario, the analysis of the metabolic behavior of the fermentative microorganisms under VHGF is a key step to improve the alcoholic fermentation process. With this aim, the identification and the importance of different $S$. cerevisae proteins during fermentation such as heat shock proteins and enzymes from the glycolytic pathway, differently expressed according to the fermentation conditions, have been reported [1315]. Despite the description of the $S$. cerevisiae KAY446 proteome under VHGF [16], this manuscript describes, for the first time, the proteome analysis of the robust yeast $S$. cerevisiae CAT-1 under VHGF aiming to understand the metabolic differences compared to the fermentation at low sugar concentration (14\%). Some fermentative parameters such as cell growth and viability, consumption of sugars and ethanol production were evaluated during the fermentation using sugar-cane juice.

\section{MATERIAL AND METHODS}

\subsection{Microorganism and culture conditions}

The yeast Saccharomyces cerevisiae strain CAT-1 was maintained in slants of YPD-agar medium (yeast extract $10 \mathrm{~g} / \mathrm{L}$, peptone $20 \mathrm{~g} / \mathrm{L}$, glucose $20 \mathrm{~g} / \mathrm{L}$ and agar $20 \mathrm{~g} / \mathrm{L}$ ) previously autoclaved at $120^{\circ} \mathrm{C}, 1.5 \mathrm{~atm}$ for $20 \mathrm{~min}$. After growth at $37^{\circ} \mathrm{C}$ for $48 \mathrm{~h}$, the cultures were maintained at $4^{\circ} \mathrm{C}$ for up to 15 days, a period that was considered appropriate for the maintenance of the cell viability. The pre-inoculum was prepared according to the process described by Moreira et al. (2015) [17] with some modification. Yeast cells from the slants were added to a tube containing $4 \mathrm{~mL}$ of distilled water sterilized; after homogenization of the suspension, $1 \mathrm{~mL}$ was added to Erlenmeyer flasks containing YPSac $10 \%$ medium (yeast extract $10 \mathrm{~g} / \mathrm{L}$, peptone 10 $\mathrm{g} / \mathrm{L}$ and sucrose $100 \mathrm{~g} / \mathrm{L}$ ), with $\mathrm{pH}$ adjusted to 5.0. The medium was previously autoclaved in the same conditions described above. The medium containing the yeast cells was maintained at $30^{\circ} \mathrm{C}$ at $250 \mathrm{rpm}$ for $20 \mathrm{~h}$ to obtain the cell concentration to conduct the fermentation with high cell density. After this period, the medium containing the cells was centrifuged at $3,100 \mathrm{x} g$ for $10 \mathrm{~min}$ at $4^{\circ} \mathrm{C}$. The cells obtained were washed with a cold solution of $\mathrm{NaCl}$ $(0.85 \% \mathrm{~m} / \mathrm{V})$, submitted to the vortex and centrifuged in the same conditions described previously. Thereafter, the cells were inoculated in $125 \mathrm{~mL}$ Erlenmeyer flasks containing $25 \mathrm{~mL}$ of sugarcane juice with the content of sucrose adjusted to $21 \%$ and $30 \%$ or without adjustment $(14 \%)$, or to the medium containing $2 \%$ sucrose. The cultures were maintained at $37.5^{\circ} \mathrm{C}$ for $10 \mathrm{~h}$. Samples $(300 \mu \mathrm{L})$ were withdrawn at $2.5 \mathrm{~h}$ intervals and used for the analysis of the fermentative parameters.

\subsection{Obtainment of cells, lysis and protein extract}

After cultivation, the culture medium containing the yeast cells was centrifuged at $3,100 \mathrm{x} g$ for $15 \mathrm{~min}$ at $4^{\circ} \mathrm{C}$. The cells obtained were separated from the liquid, washed with a solution of $\mathrm{NaCl}(0.85 \%, \mathrm{~m} / \mathrm{V})$ and centrifuged in the same condition described above. This procedure was performed three times. After the last centrifugation step, the cells were submitted to maceration using liquid nitrogen in a porcelain mortar. The proteins extracted were solubilized using an extraction buffer composed of $100 \mathrm{mM}$ Tris- $\mathrm{HCl} \mathrm{pH}$ 8.0, $1 \mathrm{mM}$ PMSF, $1 \mathrm{mM}$ EDTA, $2 \mathrm{mM}$ DTT and 2 $\mathrm{mM}$ benzamidine (modified from Moazed and Johnson) [18]. After solubilization, the content was centrifuged at 3,100x $g$ for 15 $\min$ at $4^{\circ} \mathrm{C}$ and the supernatant was used as protein crude extract.

The protein extract was precipitated with $40 \%$ TCA for $24 \mathrm{~h}$ at $4^{\circ} \mathrm{C}$. Thereafter, the material was centrifuged at 9,300x $\mathrm{g}$ for $20 \mathrm{~min}$ at $4^{\circ} \mathrm{C}$. The protein pellets obtained were washed two times with cold acetone and maintained at room temperature for $5 \mathrm{~h}$ to enable the total evaporation of the acetone. Two $\mu \mathrm{g}$ of protein was used for $1 \mathrm{~mL}$ of re-hydration buffer (urea 8M, CHAPS 2\%, 50 mM DTT, Bio-Lyte $0.2 \%$ and bromophenol blue $0.001 \%$ ). After solubilization, the extract was aliquoted and stored at $-20^{\circ} \mathrm{C}$ for use in the $2 \mathrm{D}$ electrophoresis.

\subsection{Protein quantification}

The quantification of total proteins present in the crude extract used for proteomic analysis was carried out according to the methodology described by Bradford [19] using bovine serum albumin as standard. The protein concentration was expressed as $\mathrm{mg}$ of protein per $\mathrm{mL}$ of sample.

\subsection{Electrophoresis}

The protein extracts yielded after the lysis of cells, obtained for each cultivation condition, were used for SDS-PAGE 
electrophoresis according to Laemmli (1970) [20] using gradient gels (4-15\%) (Mini-PROTEAN TGX Gel, BioRad). The power source was adjusted to $120 \mathrm{~V}, 8 \mathrm{~W}$ and $20 \mathrm{~mA} / \mathrm{gel}$ and electrophoretic run was conducted using a Mini-PROTEAN Tetra Cell (Bio-Rad) apparatus. After running, the gels were removed and stained with Comassie Brilliant Blue R-250. The gels were decolorized using a solution of methanol $(45 \%, \mathrm{v} / \mathrm{v})$ and acetic acid $(10 \%, \mathrm{v} / \mathrm{v})$ until the visualization of the protein bands.

\subsection{D-Electrophoresis}

The isoelectric focusing was conducted using $7 \mathrm{~cm}$ IPG strips at $\mathrm{pH}$ range 3.0 to 10.0 (BioRad). $125 \mu \mathrm{L}$ of protein extract ( $250 \mu \mathrm{g}$ of protein) was used to re-hydrate the strips passively for $18 \mathrm{~h}$. After this step, the isoelectric focusing was conducted in the Protean IEF Cell (BioRad) adjusted at $50 \mu \mathrm{A}$ and with 4 steps, as follows: $250 \mathrm{~V}$ for $15 \mathrm{~min} ; 4,000 \mathrm{~V}$ for $1 \mathrm{~h} ; 4,000 \mathrm{~V}$ to 15,000 for $1 \mathrm{~h}$ and $500 \mathrm{~V}$ as the rold condition. The focusing was conducted for 6 h. After this step, the IPG strips were removed and immersed for $15 \mathrm{~min}$ in the equilibrium buffer I (BioRad) $(375 \mathrm{mM}$ Tris- $\mathrm{HCl} \mathrm{pH}$ 8.8, $6 \mathrm{M}$ urea, 2\% DTT, 2\% SDS and $0.001 \%$ bromophenol blue and $30 \%$ glycerol). Thereafter, the strips were immersed for 15 $\mathrm{min}$ in the equilibrium buffer II (BioRad) $(375 \mathrm{mM}$ Tris- $\mathrm{HCl} \mathrm{pH}$ $8.8,6 \mathrm{M}$ urea, $2 \%$ SDS, $30 \%$ glycerol and $25 \mathrm{mg} / \mathrm{mL}$ iodecetamide). After the re-hydration, the strips were immersed in the running buffer composed of $25 \mathrm{mM}$ Tris- $\mathrm{HCl}, 1.92 \mathrm{mM}$ glycine and $0.1 \%$ SDS for 5 min under agitation and used in the second dimension step in a $12 \%$ SDS-PAGE. The run was conducted for $2 \mathrm{~h}$ under $8 \mathrm{~W}, 120 \mathrm{~V}$ and $20 \mathrm{~mA}$ using a PowerPac Universal Power Supply (BioRad). After the run, the gel was washed three times with milli-Q water $(5 \mathrm{~min}$ each) and fixed using a solution of $2 \%$ phosphoric acid and $2 \%$ methanol for $1 \mathrm{~h}$, washed with milli-Q water and stained with Blue Silver [21] for 12 h. The gels were decolored with milli-Q water until the visualization of the protein spots. The gel images were captured using a densitometer GS-800 (BioRad) and the Quantity One software (BioRad). The analysis of the images was made using the PDQuest software (BioRad). Four biological replicates were considered for each condition analyzed. Statistical analyses were performed using ANOVA with 95\% confidence level. Differences among protein spots with $p$ value less than 0.05 were considered significant $(p<0.05)$.

\subsection{Trypsin digestion and Mass Spectrometry}

After the analysis of the images, the protein spots differently expressed for each condition (14\% and 30\% sucrose) were excised, inserted in a $1.5-\mathrm{mL}$ micro tube and added with 250 $\mu \mathrm{L}$ of a solution composed of (v/v) 50\% ammonium bicarbonate ( $0.1 \mathrm{M}, \mathrm{pH} 8.0)$ and $50 \%$ acetonitrile P.A. for $3 \mathrm{~h}$. Thereafter, the solution was removed and $700 \mu \mathrm{L}$ of this same solution was added, maintained for $12 \mathrm{~h}$ and then removed. For full dehydration, the tubes were added with $250 \mu \mathrm{L}$ of acetonitrile P.A. and maintained for $2 \mathrm{~h}$ without agitation. After this period, the solution was removed and the tube was maintained at room temperature for 24 h. The dehydrated gels were transferred to tubes of $0.5 \mathrm{~mL}$ and added with $2.5 \mu \mathrm{L}$ Trypsin (Promega) and $17 \mu \mathrm{L}$ ammonium bicarbonate buffer $(1 \mathrm{M}, \mathrm{pH} 8.0)$, and maintained at $37^{\circ} \mathrm{C}$ for $2 \mathrm{~h}$. After this period, the tubes were added with $150 \mu \mathrm{L}$ of ammonium bicarbonate and maintained at room temperature for $22 \mathrm{~h}$. The tryptic digestion was stopped by the addition of $4 \mu \mathrm{L}$ formic acid P.A. for $2 \mathrm{~h}$. Previously to the analysis, each material digested was loaded in a Poros 50 R2 reverse phase column (PerSeptive Biosystems). The purified peptides were hydrated with $6 \mu \mathrm{L}$ of matrix solution composed of $5 \mathrm{mg} / \mathrm{mL} \quad \alpha$-cyano-4hidroxycinnaminic acid in 50\% acetonitrile $(\mathrm{v} / \mathrm{v})$ and $0.1 \%$ trifluoroacetic acid (v/v). Thereafter, $2 \mu \mathrm{L}$ of each protein sample was applied in the MALDITOF/TOF plate (Axima performance, Kratos - Shimadzu, Manchester, UK.) and the MS/MS profile for each protein digested was analyzed using the MASCOT software (Matrix Science, London, UK) and NCBInr database.

\subsection{Analysis of the Fermentative Parameters 2.6.1 Cell growth and viability}

The cell growth was determined through the biomass determination for each fermentative condition (2\% sucrose as control; $14 \%$ and $21 \%$ sucrose as HGF; $30 \%$ sucrose as VHGF) at $540 \mathrm{~nm}$ according to the equation:

Cell concentration $=$ Abs $540 \mathrm{~nm}$ x dilution $\mathrm{x} \mathrm{f}(0.67 \pm 0.05$ for $S$. cerevisae)

The cell viability was determined using methylene blue according to Shen et al. (2014) [22]. The analysis was performed on a microscope using an objective lens of 40X.

\subsubsection{Determination of the consumption of carbon source and ethanol production}

The evaluation of the consumption of the carbon source for each fermentative condition, as described above, was performed using DNS (3, 5-Dinitrosalicylic acid) according to Miller (1959) [23], at $546 \mathrm{~nm}$. For ethanol quantification, the ethanol determination kit (Sigma-Aldrich) was used, according to the methodology described by Zanon et al. (2006) [24], at $340 \mathrm{~nm}$.

\section{RESULTS AND DISCUSSION}

The yeast $S$. cerevisiae CAT-1 was able to grow under all sucrose concentrations $(2 \%, 14 \%, 21 \%$ and $30 \%)$ used for the fermentative process. As it can be observed in the figure $1 \mathrm{~A}$, the cell viability was not drastically modified (96-100\%) considering the different sucrose concentration adjusted in the fermentative medium for all periods analyzed. However, it is evident that the viability found at $30 \%$ sucrose after $10 \mathrm{~h}$ of fermentation was higher than that observed for the conditions containing $14 \%$ and $21 \%$ sucrose. The cell viability is an important factor for the alcoholic fermentation with direct relation with the product obtained. Drastic cell death can compromise ethanol production. According to the figure $1 \mathrm{~B}$, it is possible to observe an increase in the dried biomass for each fermentative condition (Figure 1B) considering that in the periods of fermentation, a 5.4-fold biomass increase is compared to the initial period. 

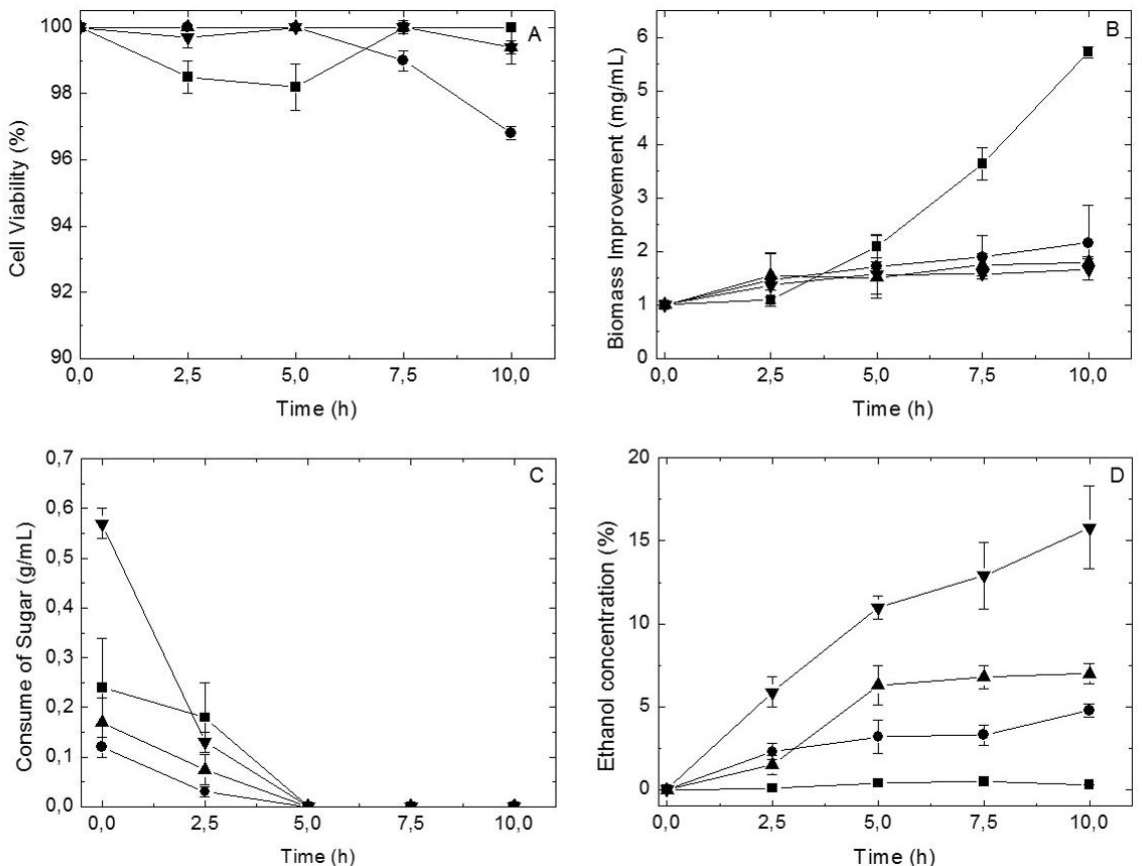

Fig. 1: Cell viability (A), biomass increasing (B), consume of sugar (C) and ethanol production (D) for S. cerevisiae CAT-1 cultured in sugar cane juice containing $2 \%$ (square), $14 \%$ (circle), $21 \%$ (up triangle) and 30\% (down triangle) sucrose for different periods.

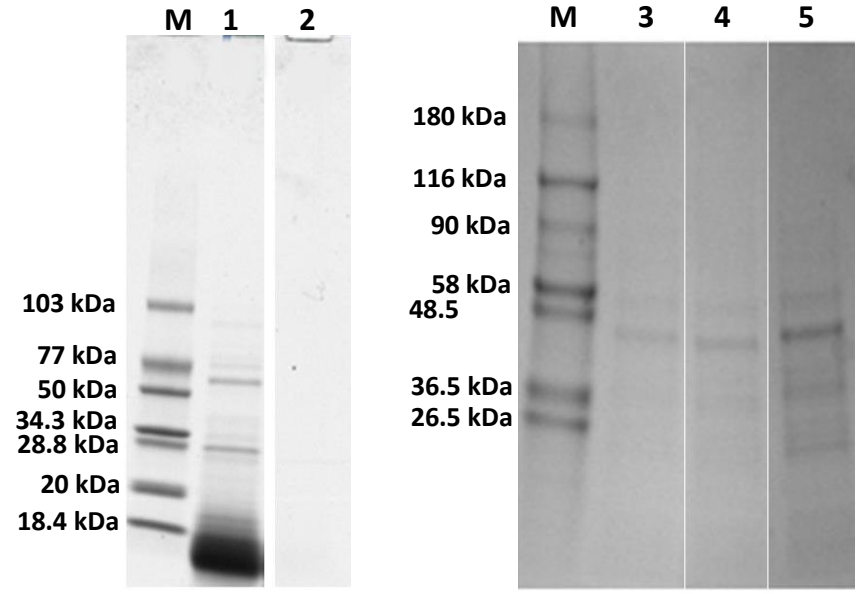

Fig. 2: Electrophoretic profile at 4-15\% SDS-PAGE for intracellular proteins obtained through culturing S. cerevisiae CAT-1 in the sugar cane juice containing $2 \%$ (lane 1), $14 \%$ (lane 3), 21\% (lane 4) and 30\% (lane 5) sucrose. $\mathrm{M}=$ molecular mass markers; Lane 2 = control (most without sucrose).
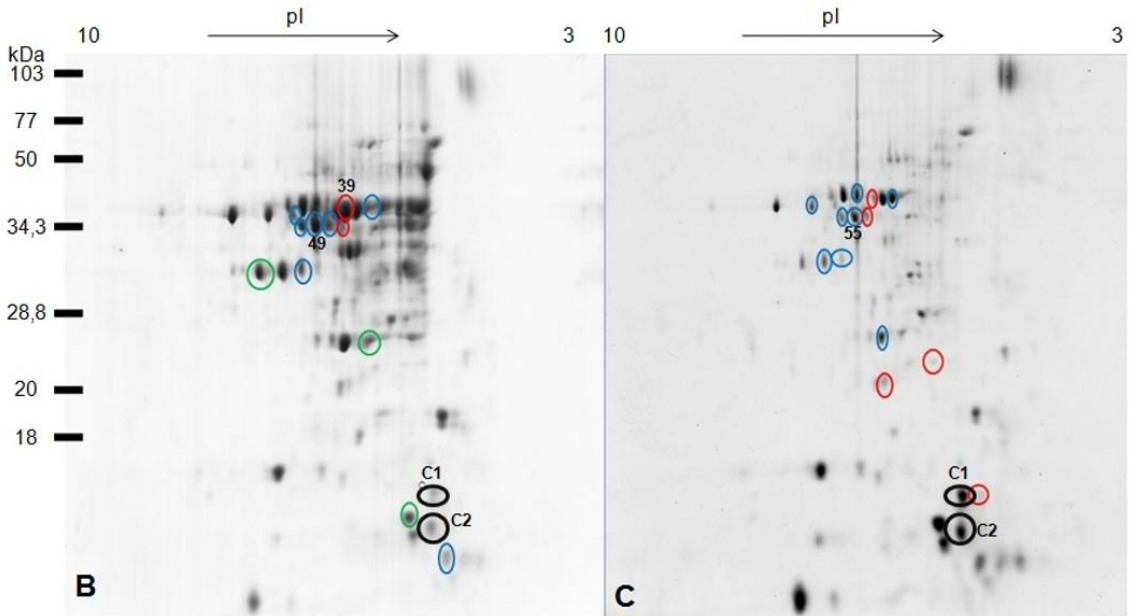

Fig. 3: Two-dimensional electrophoresis profile for proteins obtained from the S. cerevisae CAT-1 cultured in sugar cane juice containing $30 \%$ sucrose (A) and $14 \%$ sucrose (B). The red and blue circles indicate the protein spots quantitatively different and the green circles indicate the protein spots qualitatively different. 
These data indicate that the metabolic way was directed to cell growth and development. At $21 \%$ and $30 \%$ sucrose, there is no significant difference in the dried biomass. The figure $1 \mathrm{C}$ presents the use of sucrose during the fermentative process. It can be noted that, for 5-hour fermentation, the sucrose was fully consumed regardless of its initial concentration. The figure 1D shows the ethanol production under each fermentative condition used. The highest ethanol recovery was obtained under $30 \%$ sucrose in the fermentative medium. Under this condition, the ethanol recovery was 2.5-, 3.5- and 53-fold higher than that found for $21 \%, 14 \%$ and $2 \%$ sucrose in the fermentative medium. The recovery obtained at $30 \%$ sucrose was $15.99 \pm 1.38 \%$, near the theoretic value (Table 1). When the sucrose was fully consumed $(5 \mathrm{~h})$, the ethanol production continued, but its slope was reduced. The same phenomenon was observed for $S$. cerevisiae and Saccharomyces ludwigii in the presence of additional glucose in the fermentative medium [25]. Mash with high sugar concentration containing glucose as carbon source added with maize syrup, urea and metallic ions promoted ethanol recovery of $19 \%$ [26].

Supplementation of the medium with the nitrogen source available and amino acids has also been applied to improve ethanol recovery [27]. Alternatively, the use of inoculum with high cell density has been mentioned as a good option for the supplementation of the fermentative medium [28]. According to Betite et al. (2012) [29], supplementation of VHGF with peptone and ammonium sulphate as nitrogen sources promoted an increase in the biomass and improved the fermentation. In the present work, $16 \%$ of ethanol recovery was obtained using S. cerevisiae CAT-1 under VHGF without the addition of nitrogen sources, which is a very interesting value considering the theoretic value and reduction of the fermentative process cost. It is important to remember that the ethanol concentration during the process can be inhibitory to the microorganism, but as presented in the viability data, the yeast $S$. cerevisiae CAT-1 has good tolerance to ethanol.

Table 1: Alcohol recovery for fermentation using 14\%, 21\% and 30\% of dissolved solids in the sugar cane juice.

\begin{tabular}{ccc}
\hline \multirow{2}{*}{ Dissolved solids (\%) } & \multicolumn{2}{c}{ Ethanol Recovery (\%) } \\
\cline { 2 - 3 } & Real & Theoretical \\
\hline 14 & $4.80 \pm 0.22$ & 7 \\
21 & $7.06 \pm 0.06$ & $7-11$ \\
30 & $15.99 \pm 1.38$ & $17-19$ \\
\hline
\end{tabular}

After studying some fermentative parameters, the aim was focused on the analysis of proteome of $S$. cerevisiae CAT-1 cultured in both $14 \%$ and $30 \%$ sucrose in the medium to observe the yeast responses when submitted to VHGF. Most protein spots were obtained at a pI range 5.0-8.0 for both conditions. Considering the replicates for each culture condition, at $14 \%$ of sucrose, 107 protein spots were obtained, while at $30 \%$ of sucrose, 137 protein spots were obtained. Some of these protein spots are present in both conditions, but others are specific for $14 \%$ of sucrose and for $30 \%$ of sucrose.

The quantitative analysis, i.e., the evaluation of the expression level (increase in the expression of a specific protein when both conditions are compared), showed 15 different protein spots while the qualitative analysis indicated the presence of 3 different spots. In total, 27 protein spots with significant differences (statistical, quantitative and qualitative) were submitted to the identification and only 17 protein spots were effectively identified according to their tryptic peptides using the Mascot software (Table S1). Properties for each protein spot identified, such as pI and molecular mass, as well as similarity and function, are reported in the Table 2.

Most proteins identified are involved in glycolysis and fermentation pathways, showing differences in their expression levels under VHGF and HGF, as also pointed out by Pham et al. (2006) [16] for the proteomic analysis of S. cerevisiae KAY446. The protein identified as phosphopiruvate hydratase (enolase) ENO2p is an important enzyme in the glycolytic pathway responsible to convert the 2-phosphoglycerate into phosphoenolpyruvate. According to this, the ENO2p presents a direct impact on the ethanol production during the fermentative process $[13,30]$, what can explain its increased expression in the condition of $30 \%$ of sucrose, 2 -fold higher than that observed in the condition with $14 \%$ of sucrose. Another important protein for the ethanol production, the alcohol dehydrogenase (ADH1p), is responsible for the reduction of the acetaldehyde to ethanol [31], what justifies the presence of multiple protein spots for this enzyme.

In general, the protein spots identified as ADH1p were more expressed under $30 \%$ of sucrose than $14 \%$ of sucrose. The presence of multiple ADH1p can be explained by the posttranslational processing as acetylation and phosphorylation [13]. In addition, it is possible to indicate that under high sucrose concentration, the glucose concentration obtained from sucrose hydrolysis will increase and, consequently, the production of ethanol will as well, highlighting the importance of the increased levels of $\mathrm{ADH} 1 \mathrm{p}$ in the presence of $30 \%$ of sucrose in the culture medium. Other proteins were also identified in spite of the inexistence of quantitative or qualitative differences when compared to the protein spots obtained for both $14 \%$ and $30 \%$ of sucrose as, for example, the dithiol glutarredoxine (GRX 1) and the restriction of telomere-capping protein 3 (Rtc3p), among others. The former is an important glutathione-dependent protein from the oxireductase family, responsible for the regulation of the reduced state in yeast cells, protecting these cells from the oxidative stress in the culture medium [32]. The presence of proteins involved in the responses to oxidative stress is important to understand the stress tolerance observed for CAT-1 strain, as also reported by Santos et al. (2016) [2]. The protein Rtc3p is related to the RNA metabolism [33]. However, Zhao et al. (2014) [34] demonstrated that this protein, together with other proteins, has a key function in the nitrogen metabolism in the yeast cells. Triose phosphate isomerase (TPI) is another enzyme identified with great importance in the glycolysis pathway. This enzyme is responsible for the 1,2-hydrogen shift at dihydroxyacetone phosphate (DHAP) to produce glyceraldehyde 3-phosphate (GAP) [35]. 
Table S1: Identified peptides for each spot with protein match by MS/MS

\begin{tabular}{|c|c|c|}
\hline Spot & Identified peptides & Protein (similarity) \\
\hline 1 & LVSWYDNEYGYSTR & Unnamed protein product \\
\hline 2 & TFFVGGNFK & Chain $\mathrm{A}$ - triosephosphate isomerase \\
\hline 40 & $\begin{array}{c}\text { SISIVGSYVGNR } \\
\text { VLGIDGGEGKEELFR }\end{array}$ & Alcohol dehydrogenase - ADH1 \\
\hline 43 & $\begin{array}{c}\text { DGKYDLDFK } \\
\text { IGSEVYHNLK } \\
\text { NVNDVIAPAFVK } \\
\text { VNQIGTLSESIK } \\
\text { LGANAILGVSLAASR } \\
\text { AAQDSFAAGWGVMVSHR } \\
\text { SIVPSGASTGVHEALEMR }\end{array}$ & Enolase \\
\hline 45 & $\begin{array}{c}\text { YVLEHHPR } \\
\text { ELPGVAFLSEK } \\
\text { ASAPGSVILLENLR } \\
\end{array}$ & Phosphoglycerate kinase \\
\hline 49 & $\begin{array}{c}\text { SISIVGSYVGNR } \\
\text { VLGIDGGEGKEELFR }\end{array}$ & Alcohol dehydrogenase - ADH1 \\
\hline 50 & MVSMILSIIVFGKSVR & Hut1p \\
\hline 52 & $\begin{array}{c}\text { TFFVGGNFK } \\
\text { SYFHEDDEFIADK }\end{array}$ & $\begin{array}{c}\text { Chain A Triose phosphate isomerase } \\
\text { Tpilp }\end{array}$ \\
\hline 53 & $\begin{array}{c}\text { YHIEEEGSR } \\
\text { ELPGVAFLSEK } \\
\text { ASAPGSVILLENLR }\end{array}$ & Phosphoglycerate kinase \\
\hline 54 & $\begin{array}{c}\text { GVIFYESHGK } \\
\text { SISIVGSYVGNR } \\
\text { VLGIDGGEGKEELFR }\end{array}$ & Alcohol dehydrogenase - ADH1 \\
\hline 55 & $\begin{array}{c}\text { GVIFYESHGK } \\
\text { SISIVGSYVGNR } \\
\text { VLGIDGGEGKEELFR }\end{array}$ & Alcohol dehydrogenase - ADH1 \\
\hline 56 & $\begin{array}{c}\text { SISIVGSYVGNR } \\
\text { VLGIDGGEGKEELFR }\end{array}$ & Alcohol dehydrogenase - ADH1 \\
\hline 58 & LVSWYDDEYGYSTR & Glyceraldehyde phosphate dehydrogenase - GAPDH \\
\hline 59 & $\begin{array}{l}\text { FAEQYSDAAFYK } \\
\text { AEVSSMPTLIFYK }\end{array}$ & Chain A of Mxr1-Trx2 \\
\hline A & GFGYAGSPFHR & Peptidylprolyl isomerase CPR1 \\
\hline $\mathrm{C} 1$ & HIGGNDDLQELR & Dithiol glutaredoxin GRX1 \\
\hline $\mathrm{C} 2$ & $\begin{array}{l}\text { AQVENEFGK } \\
\text { IEEVIDLILR }\end{array}$ & Rtc3p \\
\hline
\end{tabular}

Other peptide matches were found but they were not assigned to protein hits using the Mascot software.

Table 2: Identification of the protein spots from S. cerevisiae CAT-1 cultured under $14 \%$ and $30 \%$ sucrose.

\begin{tabular}{|c|c|c|c|c|c|c|c|c|}
\hline & Spot & Hits & Score & $\mathrm{Mr}$ & pI & Protein (similarity) & Function & Organism \\
\hline \multirow{7}{*}{ 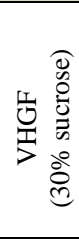 } & 1 & gi|3720 & 41 & 35.823 & 6.46 & Unnamed protein product & glycolysis & S. cerevisiae \\
\hline & 2 & gi|230405 & 78 & 26.762 & 5.75 & Chain A - triosephosphate isomerase & glycolisys & S. cerevisiae \\
\hline & 40 & gi|3339 & 51 & 37.256 & 6.26 & Alcohol dehydrogenase - ADH1 & fermentation & S. cerevisiae \\
\hline & 43 & gi|171455 & 171 & 46.830 & 10.16 & Enolase & glycolysis & S. cerevisiae \\
\hline & 45 & gi|10383781 & 85 & 44.768 & 7.11 & Phosphoglycerate kinase & glycolysis & S. cerevisiae \\
\hline & 49 & gi|3339 & 73 & 37.256 & 6.26 & Alcohol dehydrogenase - ADH1 & fermentation & S. cerevisiae \\
\hline & 50 & gi|6325012 & 46 & 38.335 & 9.76 & Hut1p & Protein folding & S. cerevisiae \\
\hline \multirow{8}{*}{ 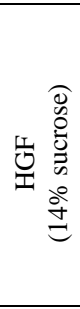 } & 52 & gi|230405 & 103 & 26.762 & 5.75 & Chain A Triose phosphate isomerase & & S. cerevisiae \\
\hline & 52 & gi|323309847 & 156 & 26.873 & 5.53 & Tpilp & glycolysis & S. cerevisiae \\
\hline & 53 & gi|10383781 & 79 & 44.768 & 7.11 & Phosphoglycerate kinase & glycolysis & S. cerevisiae \\
\hline & 54 & gi|3339 & 231 & 37.256 & 6.26 & Alcohol dehydrogenase - ADH1 & fermentation & S. cerevisiae \\
\hline & 55 & gi|3339 & 241 & 37.256 & 6.26 & Alcohol dehydrogenase - ADH1 & fermentation & S. cerevisiae \\
\hline & 56 & gi|3339 & 114 & 37.256 & 6.26 & Alcohol dehydrogenase - ADH1 & fermentation & S. cerevisiae \\
\hline & 58 & gi|229428 & 94 & 35.638 & 9.17 & $\begin{array}{l}\text { Glyceraldehydephosphate } \\
\text { dehydrogenase - GAPDH }\end{array}$ & glycolysis & Saccharomycetales \\
\hline & 59 & gi|122920148 & 126 & 12.264 & 6.02 & Chain A of Mxr1-Trx2 & Cell protection & S. cerevisiae \\
\hline \multirow{3}{*}{ స్ّ } & A & gi|6320359 & 72 & 17.494 & 6.9 & Peptidylprolyl isomerase CPR1 & $\begin{array}{l}\text { Protein folding and } \\
\text { sporulation }\end{array}$ & S. cerevisiae \\
\hline & $\mathrm{C} 1$ & gi|6319814 & 41 & 12.486 & 4.98 & Dithiol glutaredoxin GRX1 & Cell protection & S. cerevisiae \\
\hline & $\mathrm{C} 2$ & gi|6321879 & 68 & 12.002 & 5.05 & Rtc3p & Nitrogen metabolism & S. cerevisiae \\
\hline
\end{tabular}

Only 27 protein spots with significant differences (statistical, quantitative and qualitative) were submitted to the identification and 17 protein spots were effectively identified. Identification of protein spots with score value lower than 20 were not considered. 
The phosphoglycerate kinase (PGK) is another important enzyme in the glycolysis pathway responsible to catalyze the transfer of a phosphate group from 1,2-bifosfoglycerate to ADP producing ATP and 3-phosphoglycerate. In the gluconeogenesis, this enzyme catalyzes the reverse reaction producing ADP and 1,2biphosphoglycerate. It has been demonstrated that the PGK over expression could be related to the higher production of intracellular ATP in pre-apoptotic yeast cells, restoring the normal aging of the Saccharomyces cells [36].Triose phosphate isomerase is a key enzyme in both glycolysis and gluconeogenesis. This enzyme catalyzes the reversible reaction of glyceraldehyde 3phosphate to dihydroxyacetone phosphate. The protein identified as Hut1p, an UDP-galactose transporter was shown to be involved in the maintenance of the optimal environment for protein folding in the endoplasmic reticulum in $S$. cerevisae cells and in Schizosaccharomyces pombe cells [37]. Peptidyl prolyl isomerase CPR1 is a conserved cyclophilin from yeast to human, but it is not essential. This enzyme is related to both the peptidyl-prolyl isomerization during protein folding or conformational changes and the meiosis to promote an efficient sporulation when associated with other two proteins from the histone deacetylase complexes and in the glucose-stimulated transport of fructose-1,6bisphosphatase into Vid vesicles[38, 39]. The protein Mxr1-Trx2 is a methionine $\mathrm{S}$-sulfoxide reductase that uses thioredoxin as electron donor [40, 41]. Both thioredoxin-1 (Trx1) and thioredoxin-2 (Trx2) were previously identified in the quantitative proteome analysis of $S$. cerevisiae CAT-1, constituting important elements in the stress tolerance observed for this yeast [2]. Glyceraldehyde 3-phosphate dehydrogenase (GAPDH), an important enzyme in the carbohydrate metabolism, is responsible for the oxidative phosphorylation of glyceraldehyde-3-phosphate into 1-3-diphosphoglycerate in the presence of nicotinamide adenine dinucleotide $\left(\mathrm{NAD}^{+}\right)$. Despite its importance for glycolysis and gluconeogenesis, studies have presented other roles of GAPDH such as DNA replication and repair, membrane fusion and transport and tRNA export, [42].

Different authors have reported the analysis of the $S$. cerevisiae proteome [15, 34, 43], but not specifically for the CAT1 strain. Recently, Santos et al. (2016) [2] analyzed the proteome of $S$. cerevisiae CAT-1 and they found 16 proteins up regulated when the yeast was maintained under batch fermentation using a synthetic medium. Proteins, heat shock, cell membrane and cell wall proteins, among others, were identified. Differently, we described the proteome analysis under VHGF using sugarcane juice as the fermentative medium, finding especially proteins involved in the fermentation.

\section{CONCLUSION}

The proteome analysis of the yeast $S$. cerevisiae CAT-1 submitted to VHGF using high cellular density revealed qualitative and quantitative differences in the protein expression when compared to HGF condition. Most of the proteins identified have an important role in the glycolysis pathway. The increased expression of some proteins under VHGF, such as ENO2p, can explain the improvement in the ethanol production. In spite of the high ethanol concentration under VHGF condition, the cell viability was also improved, what is important to the fermentative process. The robustness of the CAT-1 strain was confirmed, reinforcing its potential to be used for high ethanol recovery, using VHGF technology with high cell density, from sugar cane juice, what can positively impact on the ethanol market.

\section{ACKNOWLEDGMENTS}

We thank Maurício de Oliveira for the technical assistance. This manuscript is part of the G.S.A. Master Dissertation presented to the Institute of Chemistry of AraraquaraUNESP, Araraquara, São Paulo, Brazil.

Financial support and sponsorship: The authors kindly acknowledge the financial support from FAPESP (2011/50880-1) and the research scholarships from Coordenação de Aperfeiçoamento de Pessoal de Nível Superior (CAPES).

Conflict of Interests: There are no conflicts of interest.

\section{REFERENCES}

1. Betite VC, Miranda-Júnior M, Oliveira JE,Ernandes JR. Very high gravity sucrose fermentation by Brazilian industrial yeast strains: effect of nitrogen supplementation. J Inst Brew 2012; 118:174-178.

2. Santos RM, Nogueira FCS, Brasil AA, Carvalho PC, Leprevost FV,Domont GB, Eleutherio ECA. Quantitative proteomic analysis of the Saccharomyces cerevisiae industrial strains CAT-1and PE-2. J Proteomics. 2016. DOI: 10.1016/j.jprot.2016.08.020.

3. Reis VR, Bassi APG, Silva JCG, Ceccato-Antonini SR. Characteristics of Saccharomyces cerevisiae yeasts exhibiting rough colonies and pseudohyphal morphology with respect to alcoholic fermentation. Braz J Microbiol 2013; 44(4):1121-1131.

4. Basso LC, Amorim HV, Oliveira AJ,Lopes ML.Yeast selection for fuel ethanol production in Brazil. FEMS Yeast Res. 2008; 8(7):11551163 .

5. Amorim Neto HB, Yohannan BK, Bringhurst TA, Brosnan JM, Pearson SY, Walker JW,Walker GM.Evaluation of Brazilian fuel alcohol yeast strain for scotch whisky fermentations. J Institute Brewing. 2009; 3(115):198-207.

6. Babrzadeh F, Jalili R, Wang C, Shokralla S, Pierce S, RobinsonMosher A, Nyren P, Shafer RW, Basso LC,Amorim HV, Oliveira AJ, Davis RW, Ronaghi M, Gharizadeh B, Stambuk BU. Whole-genome sequencing of the efficient industrial fuel-ethanolfermentative Saccharomyces cerevisiae strain CAT-1. Mol Genet Genomics. 2012;287: 485-494.

7. Romaní A, Pereira F, Johansson B, Domingues L. Metabolic engineering of Saccharomyces cerevisiae ethanol strains PE-2 and CAT-1 for efficient lignocellulosic fermentation. Biores Technol 2015; 179:150-158.

8. Carvalho JCM,\& Sato S. Fermentação descontínua. In: Schimidell W, Lima UA, Aquarone E, Borzani W (eds.). Biotecnologia industrial: engenharia química. São Paulo Edgard Blucher, v. 2, chapter 9, pp. 205-222, 2001.

9. Basso LC, Basso TO, Rocha SN.Ethanol production in Brazil: the industrial process and its impact on yeast fermentation, In:Biofuel Production-Recent Developments and Prospects, Bernardes MAS (Ed.), ISBN: 978-953-307-478-8, InTech, Croatia, pp. 85-100, 2011.

10. Fadel M, Zohri A-NA, Makawy M, Hsona MS, Abdel-Azis AM. Recycling of vinasse in ethanol fermentation and application in 
Egyptian distillery factories. Afr J Biotechnol. 2014; 13(47):43904398.

11. Puliglunda P, Smogrovicova D, Obulam VSR,Ko S.Very high gravity (VHG) ethanolic brewing and fermentation: a research update. J Ind Microbiol Biotechnol. 2011; 38(9):1133-1144.

12. Joannis-Cassan J, Riess J, Jolibert F, Taillandier P. Optimization of very high gravity fermentation process for ethanol production from industrial sugar beet syrup. Biomass Bioenergy. 2014; 70:165-173.

13. Cheng JS, Qiab B, YYuan YJ. Comparative proteome analysis of robust Saccharomyces cerevisiae insights into industrial continuous and batch fermentation. Appl Microbiol Biotechnol. 2008; 81(2):327-338

14. Jun H, Kieselbach T, Jönsson LJ. Comparative proteome analysis of Saccharomyces cerevisiae: A global overview of in vivo targets of the yeast activator protein 1. BMC Genomics. 2012;13: 230. DOI: $10.1186 / 1471-2164-13-230$.

15. Pham TK, Wright PC.Proteomic analysis of calcium-alginate immobilized Saccharomyces cerevisiae under high-gravity fermentation conditions. J Proteome Res. 2008; 7(2):515-525.

16. Pham TK, Chong PK, Gan CS, Wright PC. Proteomic analysis of Saccharomyces cerevisiae under high gravity fermentation conditions. J Proteome Res. 2006; 5(12):3411-3419.

17. Moreira CS, Santos MSM, Barros NS, Cardoso CAL, Batistote M. Evaluation of morphological and physiological parameters of industrial yeast strains with potential biotechnological for the production of etanol. Ciência e Natura. 2015; 37(4):55-63.

18. Moazed D, Johnson AD. A Deubiquitinating enzyme interacts with SIR4 and regulates silencing in S. cerevisiae. Cell. 1996; 86:667677.

19. Bradford MM.A rapid and sensitive method for quantitation of microgram quantities of protein utilizing the principle of protein-dye binding. Anal Biochem. 1976; 72:248-254.

20. Laemmli UK.Cleavage of structural proteins during the assembly of the head of bacteriophage T4. Nature 1970; 227: 681-685.

21. Candiano G, Bruschi M, Musante L, Santucci L, Ghiggeri GM, Carnemolla B, Orecchia P, Zardi L,Righetti PG. Blue silver: a very sensitive colloidal coomassie G-250 staining for proteome analysis. Electrophoresis 2004; 25(9): 1327-1333.

22. Shen 1,Li Y, Jiang 1, Wang, X. Response of Saccharomyces cerevisiae to the stimulation of lipopolysaccharide. PLoS One. 2014;9(8): e104428.

23. Miller GL. Use of dinitrosalicylic acid reagent for determination of reducing sugar. Anal Chem. 1959;31; 426-429, 1959.

24. Zanon JP, Peres FS, Gattás EAL.Colorimetric assay of ethanol using alcohol dehydrogenase from dry baker's yeast. Enzyme Microbial Technol. 2007; 40(3):466-470.

25. Mohammadi A, Razavi SH, Mousavi SM, Rezaei K.A comparison between sugar consumption and ethanol production in wort byimmobilized Saccharomyces cerevisiae, Saccharomyces ludwigii and Saccharomyces rouxiion brewer's spent grain. Braz J Microbiol. 2011; 42:605-615.

26. Pereira FB, Guimarães PMR, Teixeira JA,Domingues L.Optimization of low-cost medium for very high gravity ethanol fermentation by Saccharomyces cerevisae using statistical experimental design. Biores Technol. 2010; 101(20):7856-7863.

27. Junior MM, Oliveira JE, Batistote M, Ernandes JR. Evaluation of Brazilian etanol production yeasts for maltose fermentation in media containing structurally complex nitrogen sources. J Inst Brew. 2012;118: 82-88.

28. Nguyen TH,Viet Man LV. Using high pitching rate for improvement of yeast fermentation performance in high gravity brewing. Int Food Res J. 2009; 16:547-554.

29. Betite VC, Júnior MM, Oliveira JE, Ernandes JR. Very high gravity sucrose fermentation by Brazilian industrial yeast strains: effect of nitrogen supplementation. JinstBrew. 2012;118: 174-178.
30. Zuzuarregui A, Monteoliva L, Gil C, Olmo ML.Transcriptomic and proteomic approach for understanding the molecular basis of adaptation of Saccharomyces cerevisae to wine fermentation. Appl Environment Microbiol. 2006;72(1): 836-847.

31. Huang EL, Orsat V, Shah MB, Hettich RL, VerBerkmoes NC, Lefsrud MG. The temporal analysis of yeast exponential phase using shotgun proteomics as a fermentation monitoring technique. J Proteomics. 2012; 75:5206-5214.

32. Molina MM, Bellí G, Torre MA, Rodríguez-Manzaneque MT,Herrero E.Nuclear monothiolglutaredoxins of Saccharomyces cerevisae function as a mitochondrial glutaredoxins. J Biol Chem. 2004; 279(50):51923-51930.

33. Gutteridge A, Pir P, Castrillo JI, Charles PD, Lilley KS, Oliver SG. Nutrient control of eukaryote cell growth: a systems biology study in yeast. BMC Biol. 2010;8: 68 .

34. Zhao S, Zhao X, Zou H, Fu J, Du G, Zhou J, Chen J. Comparative proteomic analysis of Saccharomyces cerevisae under different nitrogen sources. J Proteomics. 2014;101: 102-112.

35. Go GK, Koudelka A, Amyes TL,Richard JP. The Role of Lys-12 in catalysis by triosephosphate isomerase:A Two-Part Substrate Approach. Biochem. 2010;49(25): 5377-5389.

36. Mazzoni C, Torella M, Petrera A, Palermo V,Falcone C. PGK1, the gene encoding the glycolitic enzyme phosphoglycerate kinase, acts as a multicopy suppressor of apoptotic phenotypes in $S$. cerevisiae. Yeast. 2009; 26: 31-37.

37. Nakanishi H, Nakayama K, Yokota A, Tachikawa H, Takahashi N,Jigami Y.Hut1 proteins identified in Saccharomyces cerevisiae and Schizosaccharomyces pombe are functional homologues in the protein-folding process at the endoplasmic reticulum. Yeast. 2001:18: 543-554.

38. Arévalo-Rodríguez M,Heitman J. Cyclophilin A is localized to the nucleus and controls meiosis inSaccharomyces cerevisiae. Eukaryotic Cell. 2005;4(1): 17-29.

39. Arévalo-Rodriguez $\mathrm{M}$, Wu $\mathrm{X}$, Hanes SD, Heitman J. Prolyl isomerases in yeast. Front Biosci. 2004;9: 2420-2446.

40. Le DT, Lee BC, Marino SM, Zhang Y, Fomenko DE, Kaya A,Hacioglu E, Kwak G-H, Koc A, Kim HY,Gladyshev VN.Functional analysis of free methionine- $R$-sulfoxide reductase from Saccharomyces cerevisiae. J Biol Chem. 2009;284(7): 43544364.

41. Ma X-X, Guo P-C, Shi W-W, Luo M, Tan X-F, Chen Y,Zhou CZ.Structural plasticity of the thioredoxin recognition site of yeast methionine $S$-sulfoxide reductase Mxr1. J Biol Chem. 2011; 286(15):13430-13437.

42. Shen H, Wang H, Liu Q, Liu H, Teng M,Li X.Structural insights into RNA recognition properties of glyceraldehyde-3-phosphate dehydrogenase 3 from Saccharomyces cerevisiae. IUBMB Life. 2014; 66(9):631-638.

43. Picotti P, Bodenmiller B, Mueller LN, Domon B, Aebersold R. Full dynamic range proteome analysis of $S$. cerevisiae by targeted proteomics. Cell. 2009; 138(4):795-806.

\section{How to cite this article:}

Azarias GS, Barbosa HS, Rustiguel CB, Rosa JC, Ernandes JR, Guimarães LHS. Proteome and Fermentative Parameters of Saccharomyces cerevisiae CAT-1 under Very High Gravity Fermentation (VHGF) using sugarcane juice. J App Biol Biotech. 2017; 5 (04): 006-013. 